\title{
Age and growth of the blue shark, Prionace glauca Linnaeus, 1758, in the Northwest coast off Mexico
}

\author{
Edad y crecimiento del tiburón azul, Prionace glauca Linnaeus, 1758, \\ en la costa noroeste de México
}

\section{María del Pilar Blanco-Parra ${ }^{1}$, Felipe Galván-Magaña ${ }^{2}$ and Fernando Márquez-Farías ${ }^{3}$}

\author{
'Posgrado en Ciencias del Mar y Limnología, Universidad Nacional Autónoma de México, \\ Circuito exterior s/n, Ciudad universitaria, México D.F. 04510, México \\ ${ }^{2}$ Centro Interdisciplinario de Ciencias Marinas, IPN, Av. Instituto Politécnico Nacional $s / n$, \\ Col. Playa Palo de Santa Rita, La Paz, B.C.S. 23096, México \\ ${ }^{3}$ Instituto Nacional de la Pesca, Centro Regional de Investigación Pesquera de Mazatlán, \\ Calzada Sabalo-Cerritos s/n, Mazatlán, Sinaloa, 82010, México \\ pblanco@icmyl.unam.mx
}

\begin{abstract}
Resumen.- El tiburón azul es una de las principales especies capturadas en la pesquería artesanal en la costa noroeste de México. En ella, se estimó la edad y el crecimiento mediante el conteo de las bandas de crecimiento en el centro de las vértebras de 204 tiburones utilizando nitrato de plata para teñir los centros. Los tiburones se encontraron en un rango de tallas entre 81 y $270 \mathrm{~cm}$ de longitud total (LT), con un promedio de $165 \pm 35 \mathrm{~cm}$ y una proporción sexual de machos y hembras de $2: 1$. Los machos presentaron LT entre 81 y $270 \mathrm{~cm}(150,3 \pm$ $32,3 \mathrm{~cm}, \mathrm{n}=593$ ) mientras que las hembras se encontraron entre 90 y $252 \mathrm{~cm}$ TL $(162,7 \pm 37,5 \mathrm{~cm}, \mathrm{n}=324)$. La relación entre la LT y el radio del centro (CR) fue lineal indicando una relación positiva entre el crecimiento del centro de las vértebras y el crecimiento del organismo. El valor estimado del IAPE fue de $3,0 \%$. La edad máxima estimada en los machos fue 16 años y en las hembras, 12 años. La mayoría de los tiburones en las capturas fueron juveniles de edad cuatro $(134 \pm 13 \mathrm{~cm}$ TL) y siete $(174 \pm 21 \mathrm{~cm} \mathrm{TL})$ de los cuales $19 \%$ fueron machos y $22 \%$ hembras. Los parámetros de crecimiento de von Bertalanffy fueron: $L_{\infty}=299,85 \mathrm{~cm} \mathrm{TL}, K=0,10 \mathrm{años}^{-1}$, y $t_{0}=$ $-2,44$ años para machos y $L_{\infty}=237,5 \mathrm{~cm} \mathrm{TL}, K=0,15$ años $^{-1}, \mathrm{y}$ $t_{0}=-2,15$ años para hembras, encontrándose diferencias en el crecimiento entre sexos. Los parámetros de crecimiento estuvieron dentro del rango de valores previamente reportados para tiburón azul en el Océano Pacífico.
\end{abstract}

Palabras clave: Pesquería, Baja California Sur, bandas de crecimiento, nitrato de plata, vértebra

\section{Introduction}

The shark fishery in Mexico is the eighth most important, contributing $2 \%$ to the national fishing production (metric tons live weight) in 2005 (SAGARPA 2005). About 65\% of this was caught in the Pacific Ocean (Mendizábal-Oriza et al. 2000). The blue shark (Prionace glauca Linnaeus, 1758 ) is one of the most abundant species captured in the shark fishery of the west coast off Mexico, with catches

\begin{abstract}
The blue shark is one of the main species caught in the artisanal fisheries in the northwest coast of Mexico. The age and growth was estimated by counting the growth bands on vertebral centra stained with silver nitrate from 204 sharks. Shark sizes ranged from 81 to $270 \mathrm{~cm}$ total length (TL), with a mean of $165 \pm 35 \mathrm{~cm}$ and a sex ratio of $2: 1$ between males and females. Male lengths ranged from 81 to $270 \mathrm{~cm}$ TL (mean $150.4 \pm 32.3 \mathrm{~cm}, \mathrm{n}=593$ ) and female lengths ranged from 90 to $252 \mathrm{~cm}$ TL (mean $162.7 \pm 37.5 \mathrm{~cm}, \mathrm{n}=324$ ). The relationship between TL and the vertebral centrum radio (CR) was linear indicating a positive relationship between the vertebral centrum growth and body growth. IAPE estimated value was 3.0\%. Maximum age estimated for males was 16 years and for females, 12 years. The majority of the sharks in the catches were juveniles of age four ( $134 \pm 13 \mathrm{~cm} \mathrm{TL})$ and age seven $(174 \pm 21 \mathrm{~cm} \mathrm{TL})$ from which $19 \%$ were males and $22 \%$ were females. The von Bertalanffy growth parameters were: $L_{\infty}=299.85 \mathrm{~cm} \mathrm{TL}, K=$ 0.10 years $^{-1}$ and $t_{0}=-2.44$ years for males and $L_{\infty}=237.5 \mathrm{~cm}$ $\mathrm{TL}, K=0.15$ years $^{-1}$ and $t_{0}=-2.15$ years for females; differences in growth were found between sexes. Growth parameters were within the range of previous values reported for blue sharks in the Pacific Ocean.
\end{abstract}

Key words: Fisheries, Baja California Sur, growth bands, silver nitrate, vertebrae of 3,888 sharks in 1997 and 8,745 in 1998 (MendizábalOriza et al. 2000). The blue shark inhabits the oceanic epipelagic zone in temperate, subtropical, and tropical waters (Pratt 1979), occurring abundantly during winter and spring between $20^{\circ} \mathrm{N}$ and $40^{\circ} \mathrm{N}$ in the Pacific Ocean (Strasburg 1958). Despite the economic importance of this shark species, there is not enough knowledge about its basic biology and specific life history parameters although, some studies about age and growth have been 
done using different methodologies and in different areas. For example, Cailliet et al. (1983) and Tanaka et al. (1990) determined the age and growth parameters of the blue shark using vertebral staining techniques with silver nitrate and haematoxylin-eosin, respectively, and Nakano (1994) also published a growth curve for this species derived from observations of vertebral rings stained by silver nitrate and length frequency analysis.

Shark management and conservation has been hindered by the lack of knowledge on the population status or even the direction of population trends (Baum et al. 2003). Age and growth studies have provided information on the age of maturity, longevity, as well as on rates of mortality, reproduction, and growth (Beamish 1992). These population parameters have been useful to assess demographic characteristics of the species (Cortés 1998) and Aires-da-Silva \& Gallucci (2007) used these in a risk analysis for management. The objective of the present study was to estimate the age and determine the growth parameters of the blue shark, $P$. glauca, caught by the artisanal fishery along the west coast of the Baja California Peninsula.

\section{Material and methods}

Surveys were conducted monthly from August 2000 to January 2003 in two fishery areas on the west coast of the Baja California Peninsula (Fig.1). The total length (TL cm) and sex were obtained from 917 blue sharks. Juveniles and adult categories were assigned using the criteria proposed by Pratt (1979) as follows: males with fully calcified claspers that could be easily rotated and females with vitellogenic follicles and/or embryos in uteri were considered adults; individuals that do not meet the last characteristics were considered juveniles. TL was always measured as a straight line distance from the tip of the snout to the end of the caudal fin. For age determination, a section of two to six cervical vertebrae adjacent to the most posterior of the gill slits was removed from a total of 204 individuals. Samples were transported on ice to the laboratory to be cleaned and stored frozen $\left(-20^{\circ} \mathrm{C}\right)$. Vertebrae from two near-term embryos, $44 \mathrm{~cm}$ and $45 \mathrm{~cm} \mathrm{TL}$, were also processed.

Two vertebrae from each individual were cleaned from excess of tissue and the neural and hemal arches were removed, leaving only the centrum. One of these centrums was embedded in polyester resin and sectioned $(0.5 \mathrm{~mm}$ wide) along their mid sagittal axis with a low-speed BUEHLER $®$ saw and photographed (Fig. 2a). The digital image of the vertebrae sections was used to measure the vertebral centrum radius $(\mathrm{CR}=$ distance between the midpoint of the centrum to the distal margin of the vertebral

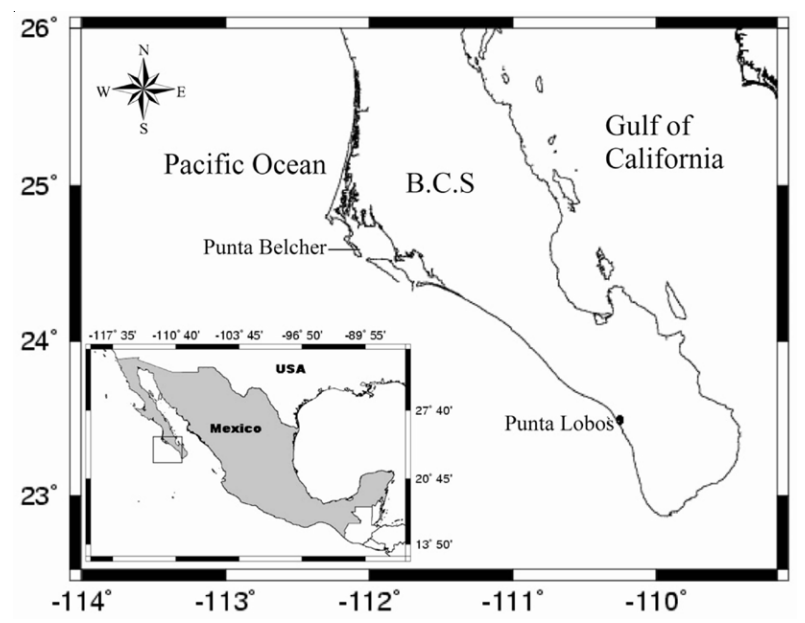

Figure 1

Sampling locations of the study area showing in the Mexican North Pacific

Lugares de muestreo del área de estudio en el Pacifico Norte mexicano

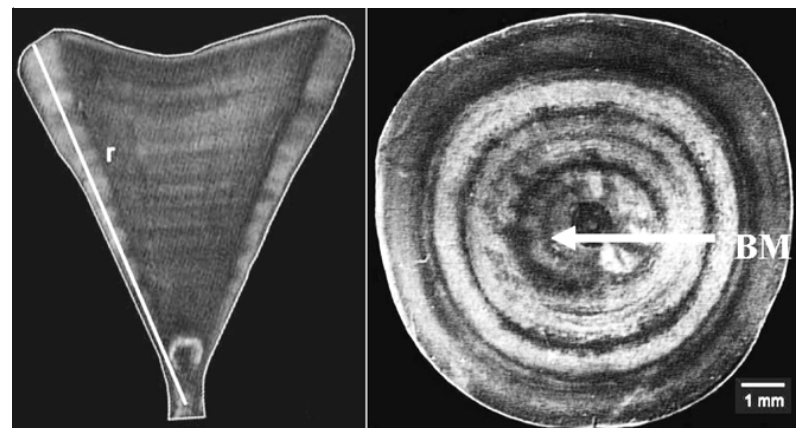

Figure 2

Blue shark vertebrae centrum radius (r) and birth mark (BM)

Radio ( $\mathrm{r}$ ) del centro de la vértebra de tiburón azul y marca de nacimiento $(\mathrm{BM})$

centrum) using Sigma Scan Pro 4.0 software (Fig. 2a). Sections were not used to estimate the age because the clarity of the bands was affected by the drying process needed to embed it into the resin. The second centrum was stained with silver nitrate (Stevens 1975) to enhance visibility of band pairs (BP) and was used to estimate age (Fig 2b). We considered a 'band pair' as a pair of one opaque and one translucent band which were assumed to represent a one year period (Cailliet et al. 1983, Nakano 1994, Skomal \& Natanson 2003, Lessa et al. 2004). The stained centrum and the centrum section of each individual were digitally photographed at $6.3 \mathrm{x}$ magnification with a CCD-IRIS Sony camera attached to a SZX-TR30 Olympus stereo microscope using reflected light. 
Three readers counted the BP from the images of the stained centrum, without any knowledge of the TL of the specimen or the counts of previous readers of the bands. Since the vertebrae centrum of the two near-term embryos did not have consistent prebirth bands, the first light band distal to the focus was defined as the birthmark; this mark was not included in the final count. Ageing bias and precision of $\mathrm{BP}$ counts were examined using age bias plots (Campana et al. 1995) and the Index of Average Percentage Error (IAPE) (Beamish \& Fournier 1981) as:

$$
I A P E=\frac{1}{N} \sum_{j=1}^{N}\left[\frac{1}{R} \sum_{i=1}^{R} \frac{\left|X_{i j}-X_{j}\right|}{X_{j}}\right] \times 100
$$

where $N$ is the number of samples, $R$ the number of readings, $X i j$ is the ith age determination of the $j t h$ fish, and $X j$ the average age calculated for the $j$ th fish.

CR to TL relationship was estimated using the linear model and was compared by sex using analysis of covariance (ANCOVA).

Centrum edge analysis is useful to determine seasonal changes in growth (Cailliet \& Goldman 2004). Analysis of the vertebra edge (Cailliet 1990) was performed in all centrums samples and was used as an indirect method to verify the periodicity of the formation of the BP. This technique determines the frequency of individuals with translucent or opaque edges in their vertebrae centrums during the sampling months (Cailliet 1990).

Growth was described by the von Bertalanffy growth function (VBGF):

$L_{t}=L_{\infty}\left(1-\exp -K\left(t-t_{o}\right)\right)$

where $L t$ is predicted length at time $t, L_{\infty}$ the mean asymptotic total length, $K$ the growth rate $\left(\mathrm{yr}^{-1}\right), t_{o}$ the theoretical age at which the fish had zero length. VBGF parameters were estimated for both sexes by fitting the VBGF to the observed data by maximizing the likelihood function (Haddon 2001). Maximization was performed with the add-inn optimization tool (solver) of Microsoft Excel $2000^{\mathrm{TM}}$. The $95 \%$ confidence interval (CI) for parameters $L_{\infty}$ and $K$ was estimated with the procedures of Venzon \& Moolgavkar (1988) and Punt \& Hilborn (1996). Differences between VBGF by sex were tested using the analysis of the residual sum of squares (ARSS) (Chen et al. 1992).

\section{Results}

Prionace glauca was the most common shark species caught during the study period representing $65 \%$ of the total number of sharks caught. The second most important species was Carcharhinus falciformis (18\%) followed by Isurus oxyrinchus $(10 \%)$ and the remaining $7 \%$ was shared among 10 other shark species (Table 1).

Blue shark was most abundant during winter-spring and occurred in a ratio of $65 \%$ males to $35 \%$ females. Male lengths ranged 81-270 cm TL (mean 150.4 \pm 32.3 $\mathrm{cm}$ ) and female lengths ranged 90-252 cm TL (mean 162.7 $\pm 37.5 \mathrm{~cm}$ ) (Fig. 3). Blue sharks less than $150 \mathrm{~cm}$ TL were most abundant in the catches (Fig. 3). Individuals used for age determination ranged $90-253 \mathrm{~cm}$ TL. Based on external features males become mature at $180 \mathrm{~cm}$ TL and females at $200 \mathrm{~cm} \mathrm{TL}$, thus, most of the sharks examined ( $75 \%)$ were immature.

The relationship between TL and CR was linear for females (slope $=91.33$, intercept $=463.4, r^{2}=0.70, P<0.01$ ) and males (slope $=95.67$, intercept $=422.32, r^{2}=0.76$, $P<0.01)$ and no differences were found between sexes (ANCOVA, $P=0.612$ ) (Fig. 4).

Readings of vertebrae age achieved a good level of agreement among the three readers $(73 \%, n=149$ measurements), whereas $17 \%(\mathrm{n}=35)$ of the measurements were variable, within a maximum of \pm 1 year of difference. Agreement was not achieved among $10 \%(\mathrm{n}=20)$ of the

\section{Table 1}

Number of sharks caught in the west coast of Baja California Sur during the sampling period, by specie and season

Número de tiburones capturados en la costa occidental de Baja California sur durante el periodo de muestreo, por especie y estación del año

\begin{tabular}{lrrrrr}
\hline \multicolumn{1}{c}{ Specie } & Winter & Spring & Summer & Autumn Total \\
\hline Prionace glauca & 258 & 470 & 117 & 72 & 917 \\
Carcharhinus falciformis & 1 & & 179 & 77 & 257 \\
Isurus oxyrinchus & 21 & 43 & 56 & 15 & 135 \\
Sphyrna zygaena & 17 & 3 & 12 & 3 & 35 \\
Alopias pelagicus & & & 12 & 5 & 17 \\
Mustelus californicus & & 17 & & & 17 \\
Sphyrna lewini & 2 & & 4 & 9 & 15 \\
Carcharhinus longimanus & & 1 & 6 & & 7 \\
Galeocerdo cuvier & 2 & & 1 & & 3 \\
Mustelus henlei & & 2 & 1 & & 3 \\
Carcharhinus limbatus & 2 & 1 & & & 3 \\
Carcharhinus leucas & 1 & & & & 1 \\
Mustelus lunulatus & & 1 & & & 17 \\
\hline \multicolumn{1}{c}{ Total } & $\mathbf{3 0 4}$ & $\mathbf{5 3 8}$ & $\mathbf{3 8 8}$ & $\mathbf{1 8 1}$ & $\mathbf{1 4 1 1}$ \\
\hline
\end{tabular}




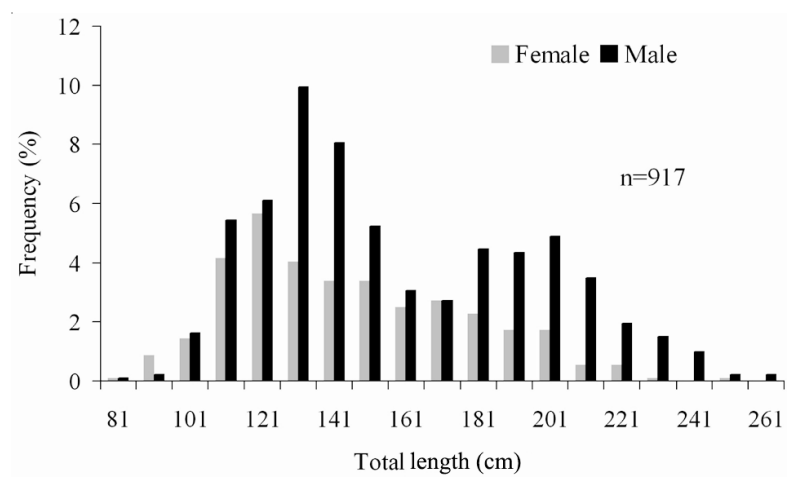

Figure 3

\section{Length-frequency distribution of blue sharks caught off} the Northwest coast of Mexico

Distribución de frecuencia de longitudes totales de los tiburones azules capturados en la costa noroeste de México

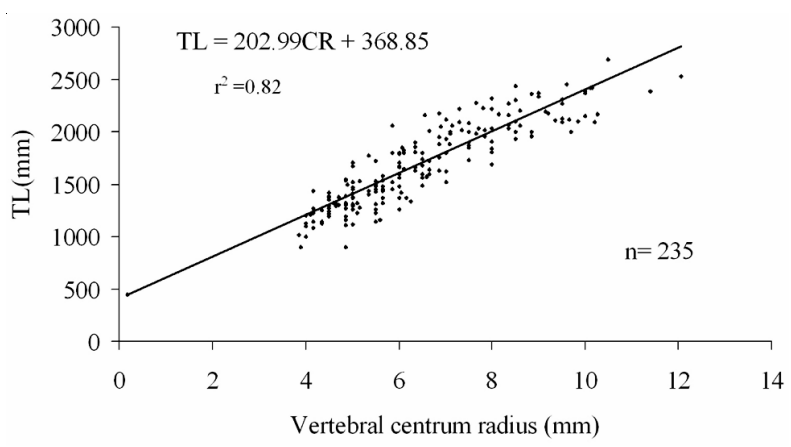

Figure 4

Relationship between vertebral centrum radius ( $\mathrm{mm})$ and total length $(\mathrm{mm})$ of blue shark

Relación entre el radio del centro de la vértebra $(\mathrm{mm})$ y la longitud total $(\mathrm{mm})$ de tiburón azul

vertebrae aged in this study, therefore, these samples were excluded from the analysis. Comparison of counts between three readers indicated no appreciable bias (Fig. 5). The IAPE value $(3.0 \%)$ was considered acceptable; thus, the counts from the three readers were combined for age estimation and comparison analyses.

The BP periodicity of formation was not clear, because it was not possible to obtain enough samples during each month of the year. Proportion between translucent and opaque edges varied among seasons, but this variation was more evident during autumn when the opaque edge was observed in $70 \%$ of the samples, although this value decreased in winter $(25 \%)$.
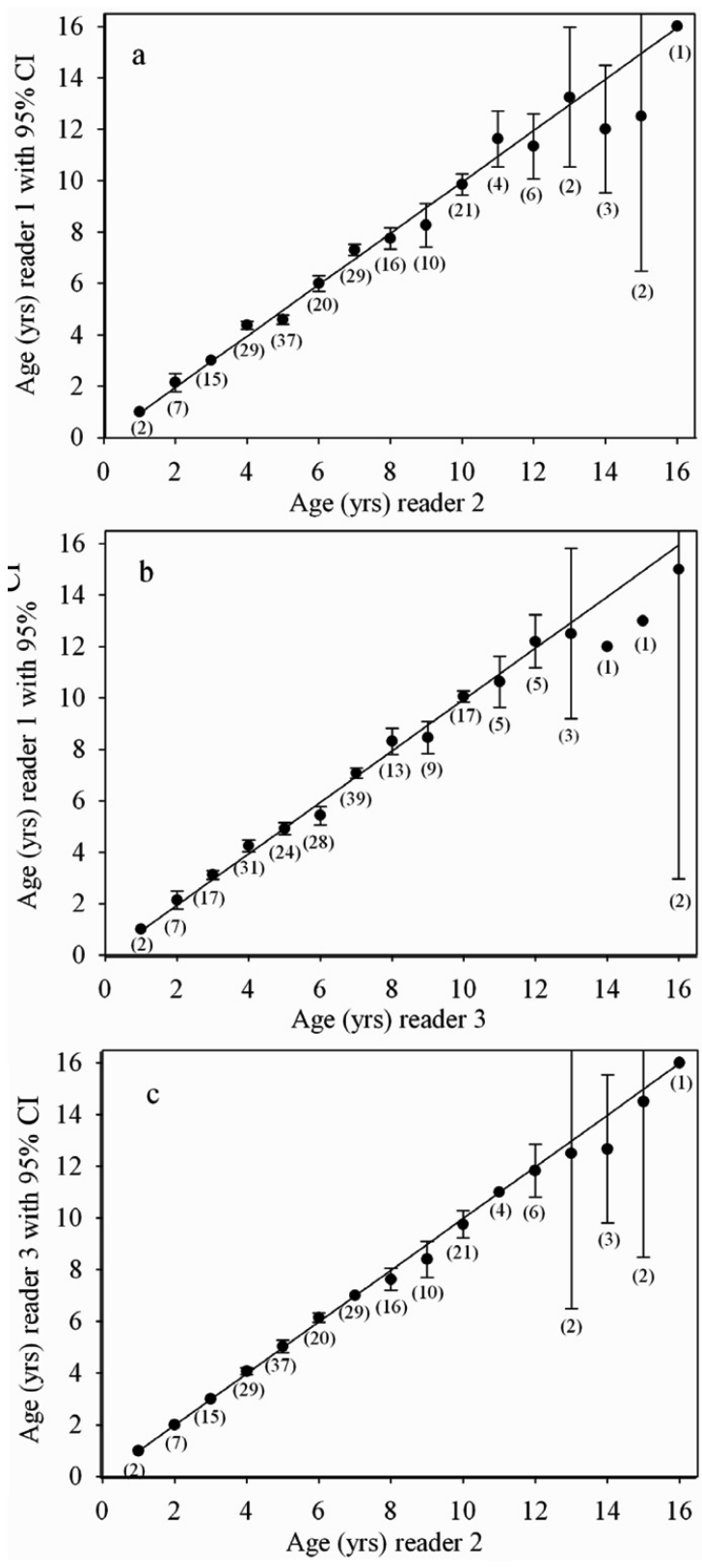

Figure 5

Age bias plots for pair-wise comparison of blue shark BP counts from three independent age readers. Each error bar represents the $95 \%$ confidence interval for the mean age assigned by one reader to all fish assigned a given age by the other reader. The 1:1 equivalence line is also presented

Gráfica de error de edad para comparaciones pareadas de los conteos de BP realizados por tres lectores de edad independientes. Cada barra de error representa el intervalo de confianza al $95 \%$ para la edad media asignada por uno de los lectores a todos los peces a los cuales les asignó una edad el otro lector. Se presenta también la línea de equivalencia 1:1 


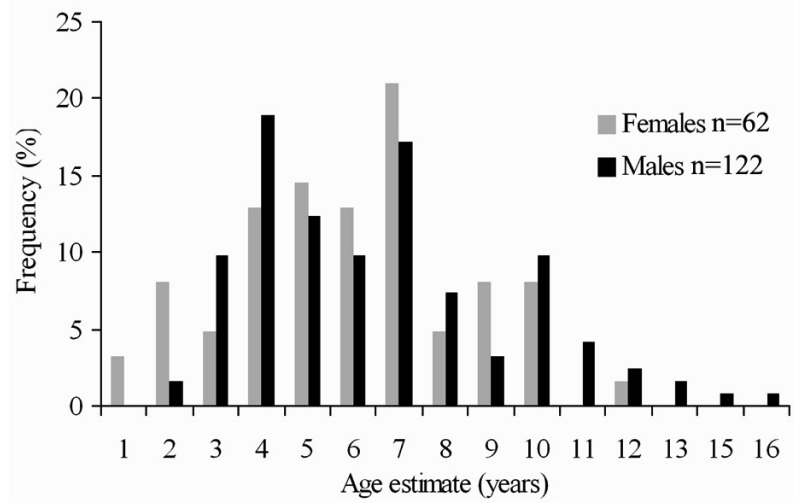

Figure 6

Distribution of individuals per age estimated (years) of the blue shark

Distribución de individuos por edad estimada (años) del tiburón azul

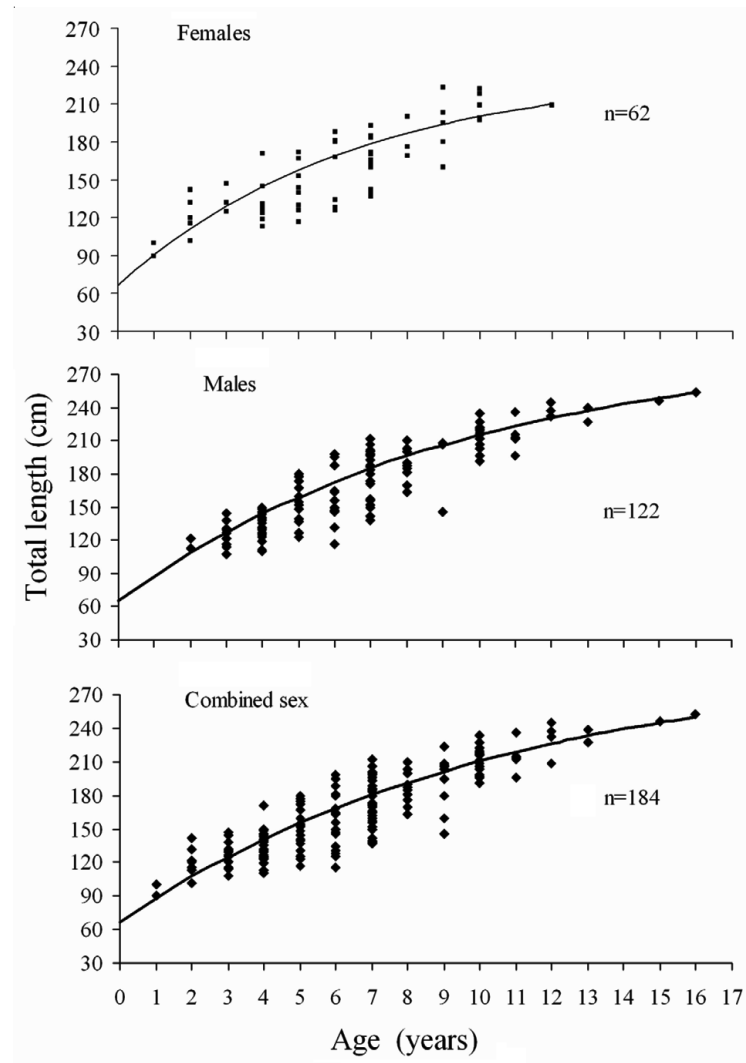

Figure 7

Growth curves (von Bertalanffy function) for male and female blue sharks determined by counting growth bands in vertebrae centrum

Curvas de crecimiento (función de von Bertalanffy) para machos y hembras de tiburón azul determinadas contando las bandas de crecimiento en el centro vertebral
The age estimates in the sampled specimens ranged from 1 to 16 years. Mean length of specimens with one BP was $95 \mathrm{~cm}$ TL. Specimens with 15 and $16 \mathrm{BP}$ corresponded to two males 246 and $253 \mathrm{~cm} \mathrm{TL}$, respectively. The greatest number of BP found in a female was 12 of $209 \mathrm{~cm}$ TL. Over half of the captured blue shark specimens had 4 to 7 BPs (Fig. 6). Growth parameters for males were $L=299.85 \mathrm{~cm} \mathrm{TL}\left(\mathrm{IC}_{95 \%}=225\right.$ $350), K=0.10$ years $^{-1}\left(\mathrm{IC}_{95 \%}=0.06-0.14\right), t_{0}=-2.44$ years (Table 1). Growth parameters for females were $L_{\infty}=237.5$ $\mathrm{cm} \mathrm{TL}\left(\mathrm{IC}_{95 \%}=160-290\right), K=0.15$ years $^{-1}\left(\mathrm{IC}_{95 \%}=0.08-0.26\right)$ and $t_{0}=-2.15$ years. Growth rate during the first year were: males $\sim 22 \mathrm{~cm}$ and females $\sim 24 \mathrm{~cm}$. Combined sexes growth parameters were $L_{\infty}=303.4 \mathrm{~cm} \mathrm{TL}\left(\mathrm{IC}_{95 \%}=235\right.$ $370), K=0.10$ year $^{-1}\left(\mathrm{IC}_{95 \%}=0.06-0.13\right)$ and $t_{0}=-2.68$ years. Differences in the growth models between sexes were found $(P<0.05)$ (Fig. 7).

\section{Discussion}

The blue shark is one of the most important shark species caught by high seas and coastal fisheries throughout the world's oceans (Nakano \& Seki 2003). In Mexico, this species represents one important resource in the Pacific coast fisheries (Mendizábal-Oriza et al. 2000). This agrees well with the present study in which the blue shark was the dominant species caught by the coastal shark fisheries in the west coast of the Baja California Peninsula.

In the North Pacific Ocean blue sharks exhibit a strong latitudinal segregation by size and sex (Nakano 1994, Nakano \& Seki 2003); male schools appear farther south (subtropical and tropical areas) than females, therefore, the high proportion of males $(2 \mathrm{M}: 1 \mathrm{~F})$ found in the study area could be an effect of this segregation reported before and the selectivity of the fishery in this area.

Nakano (1994) reported a primary region of parturition for blue sharks in the North Pacific Ocean between $35-45^{\circ} \mathrm{N}$ and a distribution of sub-adult females (between 134-199 cm TL) in this northern area, while sub-adult males (134-199 cm TL) occupy subtropical and tropical waters south of the parturition grounds. The dominance of juvenile males between 131-150 cm TL (4 and 5 years) in the study area is therefore consistent with the distribution pattern described by Nakano (1994). The large proportion of small sizes $(<150 \mathrm{~cm}$ TL) in the catches found in this study, was also reported by CastilloGéniz et al. (1998). These small sizes result from the overlapping of fishing grounds and nursery areas, and/or the capture of juveniles during their seasonal movements. In addition, catch composition in coastal fisheries may vary with type of gear and the characteristics of the environment. 
The BP annual deposition in blue sharks (up to 4+ years) form the North Atlantic have been recently validated, with the deposition occurring during spring (Skomal \& Natanson 2003). Due to the fact that blue shark catches are strongly seasonal (winter-spring) in the west coast of Baja California Peninsula, vertebrae samples were not enough to show a clear trend of low and high periods in the opaque and hyaline edge proportion throughout the year, therefore, the present study assumes the same pattern of annual deposition proposed for blue sharks from the North Atlantic (Skomal \& Natanson 2003).

The TL of blue sharks used in the present study (west coast of Baja California) ranged from 44 to $270 \mathrm{~cm}$, and their ages ranged between 0 to 16 years. A previous study using blue sharks from California, reported a similar size range (30-270 cm TL) and a maximum age of 9 years (Caillet et al. 1983), seven years under the present study age estimations. The differences found here with the California study could be due to the low number of samples from sharks over $200 \mathrm{~cm}$ TL $(n=16)$ employed in the California study, that could imply a sub-estimation in age, or by differences between methods and criteria used to estimate the age in both laboratories (Tanaka et al. 1990). Mean size at age in the first two groups is almost the same between both studies but after age three the mean size at age for blue sharks from the west coast of Baja
California is lower than that reported for California (Cailliet et al. 1983).

According to Nakano (1994) the blue sharks from the North Pacific reaches maturity at $203 \mathrm{~cm}$ TL for males and $186 " 212 \mathrm{~cm}$ TL for females, which according to our age estimates, is 8 or 9 years of age for males and 7-9 years for females. Thus, male blue sharks become reproductively mature at about $68 \%$ of our estimated asymptotic length and females between $78-89 \%$. These values coincide with those reported before for blue sharks in the North Pacific (Cailliet et al. 1983).

No previous studies on the blue shark had reported differences in the VBGF between sexes, however the estimation of separate equations have been carried out for blue sharks in the Pacific Ocean (Cailliet et al. 1983, Tanaka et al. 1990, Nakano 1994). In the present study we found differences in VBGF between sexes, males showed higher asymptotic lengths and lower growth rates than females. Skomal \& Natanson (2003) observed that female blue sharks in the western North Atlantic Ocean can reach larger sizes than males (Table 2). Opposite results were found in the present study in which male asymptotic length was higher $\left(L_{\infty}=300 \mathrm{~cm}\right.$ TL $)$ than that for females $\left(L_{\infty}=238 \mathrm{~cm} \mathrm{TL}\right)$, this findings agree with other reports for this species in the eastern North Pacific Ocean (Cailliet et al. 1983, Tanaka et al. 1990, Nakano 1994) (Table 2).

Table 2

Parameters of the von Bertalanffy growth function for blue sharks from the North Atlantic Ocean (NA), South Atlantic Ocean (SA), North Pacific Ocean (NP), North East Pacific Ocean (NEP) and North Mexican Pacific Coast (NMP). CS=combined sexes

Parámetros de la función de crecimiento de von Bertalanffy para tiburones azules del Océano Atlántico Norte (NA), Océano Atlántico Sur (SA), Océano Pacífico Norte (NP), Océano Pacífico Noreste (NEP) y costa norte del Pacífico de México (NMP). CS= sexos combinados

\begin{tabular}{|c|c|c|c|c|c|c|c|}
\hline Authors & Area & Sex & $\mathbf{n}$ & Max.age & $\mathbf{L}_{\infty}(\mathbf{c m})$ & K $\left(\right.$ year $\left.^{-1}\right)$ & $t_{0}($ years $)$ \\
\hline Skomal \& Natanson (2003) & NA & Males & 287 & 16 & *337.9 & 0.18 & -1.35 \\
\hline Cailliet et al. (1983) & NEP & Males & 38 & 9 & 295.3 & 0.18 & -1.11 \\
\hline Tanaka et al. (1990) & NP & Males & 43 & 11 & 369.0 & 0.10 & -1.38 \\
\hline Nakano (1994) & NP & Males & 148 & 10 & *382.9 & 0.13 & -0.76 \\
\hline Present study & NMP & Males & 122 & 16 & 299.8 & 0.10 & -2.44 \\
\hline Skomal \& Natanson (2003) & NA & Females & 118 & 15 & $* 343.3$ & 0.16 & -1.56 \\
\hline Cailliet et al. (1983) & NEP & Females & 88 & 9 & 241.9 & 0.25 & -0.79 \\
\hline Tanaka et al. (1990) & NP & Females & 152 & 8 & 304.0 & 0.16 & -1.01 \\
\hline Nakano (1994) & NP & Females & 123 & 10 & $* 321.4$ & 0.14 & -0.85 \\
\hline Present study & NMP & Females & 62 & 12 & 237.5 & 0.15 & -2.15 \\
\hline Lessa et al. (2004) & SA & $\mathrm{CS}$ & 236 & 11 & 331.9 & 0.16 & -2.25 \\
\hline Skomal \& Natanson (2003) & NA & $\mathrm{CS}$ & 410 & 16 & *341.6 & 0.17 & -1.41 \\
\hline Cailliet et al. (1983) & NEP & $\mathrm{CS}$ & 130 & 9 & 265.5 & 0.22 & -0.80 \\
\hline Present study & NMP & CS & 184 & 16 & 303.4 & 0.10 & -2.68 \\
\hline
\end{tabular}

*Used for converting Fork length (FL) and Precaudal length (PCL) to TL: FL $=0.8313(\mathrm{LT})+1.39$ and $\mathrm{PCL}=0.9075$ (FL) -0.3956 (Kohler et al. 1995). 
Different factors may bias estimates of growth parameters and could lead to distortions of the growth curves. Such differences can be a consequence of the methodologies, such as: prior experience of readers of growth marks, criteria used in making readings, and the staining technique used (Tanaka et al. 1990). The last criterion is particularly important because the silver nitrate technique (with or without sectioning) may cause difficulties in reading the last growth marks of adults in species with high longevity (Stevens 1975). In our study growth rates were lower than those reported by Cailliet et al. (1983) for blue sharks in California waters. Some differences (Table 2) are noted by comparing growth parameters reported in other studies (Tanaka et al. 1990, Nakano 1994). The scarcity of small $(<100 \mathrm{~cm})$ and large $(>260 \mathrm{~cm})$ individuals in this study could also influence variations among growth models (Campana 2001).

Sexual segregation and migration is another source of bias that could affect estimates of growth parameters. Well-documented long distance movements of the blue shark may confuse our interpretation regarding the age structure of populations in some areas due to the misrepresentation of some sizes or sexes in the catches (Strasburg 1958, Casey \& Kohler 1990, Nakano 1994). The study of the blue shark population in the North Pacific is difficult because the high migratory characteristic of this species. Information about the life history parameters of different segments of this population could elucidate what is happening in the entire population and are also important for future international efforts in the conservation of this species.

\section{Acknowledgments}

The senior author was supported through scholarship by the Dirección General de Estudios de Posgrado (UNAM). We greatly appreciate the support of colleagues in the 'Laboratorio de edad y crecimiento' at Centro Interdisciplinario de Ciencias Marinas. We thank Vincent Gallucci and Gregor Cailliet for their comments and suggestions, and Paul Ahuja for the English review. Galván-Magaña thanks to COFAA-IPN fellowship. The manuscript benefited from suggestions of two anonymous reviewers.

\section{Literature cited}

Aires-da-Silva A \& V Gallucci. 2007. Demographic and risk analyses applied to management and conservation of the blue shark (Prionace glauca) in the North Atlantic Ocean. Marine and Freshwater Research 58: 570-580.

Baum JK, RA Myers, D Kehler, B Worm, SJ Harley \& PA Doherty. 2003. Collapse and conservation of shark populations in the northwest Atlantic. Science 299: 389-392.
Beamish RJ \& DA Fournier. 1981. A method for comparing the precision of a set of age determinations. Canadian Journal of Fisheries and Aquatic Sciences 3: 982-983.

Beamish RJ. 1992. The importance of accurate ages in fisheries science. In: Hancock DA (ed). The measurement of age and growth in fish and shellfish, pp. 8-22. Australian Society for Fish Biology Workshop. Bureau of Rural Resources Proceedings 12. Lorane.

Cailliet GM. 1990. Elasmobranch age determination and verification: an update review. In: Pratt HL, SH Gruber \& $\mathrm{T}$ Taniuchi (eds). Elasmobranchs as living resources: advances in the biology, ecology, systematics, and status of the fisheries. NOAA Technical Report 90: 157-165.

Cailliet GM \& KJ Goldman. 2004. Age determination and validation in Chondrichthyan fishes. In: Carrier J, JA Musick \& MR Heithaus (eds). Biology of sharks and their relatives, pp. 399-447. CRC Press, Boca Raton.

Cailliet GM, LK Martin, JT Harvey, D Kusher \& BA Welden. 1983. Preliminary studies on the age and growth of blue, Prionace glauca, common thresher, Alopias vulpinus, and shortfin mako, Isurus oxyrinchus, sharks from California waters. In: Prince ED \& LM Pulos (eds). Proceedings of the International workshop on age determination of oceanic pelagic fishes: tunas, billfishes, and sharks. NOAA Technical Report NMFS 8: 179-188.

Campana SE. 2001. Accuracy, precision and quality control in age determination, including a review of the use and abuse of age validations methods. Journal of Fish Biology 59: 197-242.

Campana SE, MC Annand \& JI McMillan. 1995. Graphical and statistical methods for determining the consistency of age determinations. Transactions of the American Fisheries Society 124: 131-138.

Casey JG \& NE Kohler. 1990. Long distance movements of Atlantic sharks from the NMFS Cooperative shark tagging Program. In: Gruber SH (ed). Discovering sharks, pp. 8790. American Littoral Society, Highlands.

Castillo-Geniz JL, JF Márquez-Farias, MC Rodríguez de la Cruz, E Cortés \& A Cid del Prado. 1998. The Mexican artisanal shark fishery in the Gulf of Mexico: toward a regulated fishery. Marine and Freshwater Research 49: 611620 .

Chen Y, DA Jackson \& HH Harvey. 1992. A comparison of von Bertalanffy and polynomial functions in modeling fish growth data. Canadian Journal of Aquatic Science 49: 12281235.

Cortés E. 1998. Demographic analysis as an aid in shark stock assessment and management. Fisheries Research 39(2): 199-208.

Haddon M. 2001. Modelling and quantitative methods in fisheries, 402 pp. Chapman \& Hall/CRC, Boca Raton.

Kohler NE, JG Casey \& PA Turner. 1995. Length-weight relationships for 13 species of sharks from the western North Atlantic. Fishery Bulletin 9: 412-418. 
Lessa R, FM Santana \& FH Hazin. 2004. Age and growth of the blue shark Prionace glauca (Linnaeus, 1758) off northeastern Brazil. Fisheries Research 66: 19-30.

Mendizábal-Oriza D, R Vélez-Marín, JF Márquez-Farías \& SR Soriano-Velásquez. 2000. Tiburones oceánicos del Pacífico. In: Instituto Nacional de la Pesca (ed). Sustentabilidad y Pesca Responsable en México: Evaluación y Manejo, 1999"2000, pp. 181-209, Instituto Nacional de Pesca, México.

Nakano H. 1994. Age, reproduction and migration of blue shark in the North Pacific Ocean. Bulletin of the National Research Institute of Far Seas Fisheries 31: 141-256.

Nakano H \& MP Seki. 2003. Synopsis of biological data on the blue shark, Prionace glauca Linnaeus. Bulletin of Fisheries Research Agency 6: 18-55.

Pratt HL Jr. 1979. Reproduction of the blue shark, Prionace glauca. Fishery Bulletin 77: 445-470.

Punt AE \& R Hilborn. 1996. Biomass dynamic models. FAO Computerized Information Series Fisheries 10: 1-62.

SAGARPA 2005. Anuario Estadístico de Acuacultura y Pesca, 220 pp. Secretaría de Agricultura, Ganadería, Desarrollo Rural, Pesca y Alimentación, México.
Skomal GB \& LJ Natanson. 2003. Age and growth of the blue shark, Prionace glauca, in the North Atlantic Ocean. Fishery Bulletin 101(3): 627-639.

Stevens JD. 1975. Vertebral rings as a means of age determination in the blue shark (Prionace glauca, L.). Journal of the Marine Biological Association of the United Kingdom 55: 657-665.

Strasburg DW. 1958. Distribution, abundance and habits of pelagic sharks in the Central Pacific Ocean. Fishery Bulletin 58: 335-361.

Tanaka S, GM Cailliet \& KG Yudin. 1990. Differences in growth of the blue shark, Prionace glauca: technique or population? In: Pratt HL, SH Gruber \& T Taniuchi (eds). Elasmobranchs as living resources: advances in the biology, ecology, systematics, and status of the fisheries. NOAA Technical Report 90: 177-187.

Venzon DJ \& SH Moolgavkar. 1988. A method for computing profile-likelihood-based confidence intervals. Applied Statistics 37: 87-94.

Recibido el 13 de mayo de 2008 y aceptado el 13 de agosto de 2008 